\title{
20. PHYSICAL-PROPERTIES CHARACTERIZATION OF SEDIMENTS IN THE AREA AROUND DSDP/ODP HOLE 504B 1
}

\author{
M. A. Lovell ${ }^{2}$ and R. H. Morin ${ }^{3}$
}

\begin{abstract}
The physical properties of sediments in the region of DSDP/ODP Hole 504B are characterized by high porosities and variable carbonate content. These two parameters appear to be the dominant factors controlling the majority of the physical properties. The overall stratigraphy of the sediment column correlates well with the physical properties on this basis. Thermal-conductivity measurements correlate with both porosity and carbonate content. The high porosity of the sediment corresponds to the measurement of comparatively low electrical formation factors, although the values reported are in broad agreement with previously published data. Coring at Sites 677 and 678 on ODP Leg 111 is accompanied by considerable scatter in all measured physical properties. A power spectrum analysis of compressional-wave velocity data indicates that there may be considerable sample disturbance related to the coring technique adopted. An evaluation of the role of fluid flow on the sediment physical properties is considered. Hydraulic conductivity is estimated to be approximately $10^{-6} \mathrm{~cm} / \mathrm{s}$; consequently, anticipated fluid-flow velocities of $6 \mathrm{~mm} / \mathrm{yr}$ would have no significant effect on the mechanical characteristics of the sediments.
\end{abstract}

\section{INTRODUCTION}

Site 504 of the Deep Sea Drilling Project (DSDP)/Ocean Drilling Program (ODP) is located some $200 \mathrm{~km}$ to the south of the Costa Rica Rift in 5.9-Ma-old crust. A thick layer of pelagic sediments (between 200 and $300 \mathrm{~m}$ on average) covers the area and is thought to seal the basement effectively from the bottom water. Initial heatflow measurements suggested that the crust had reached conductive equilibrium for its age, although a recent detailed survey (Langseth et al., 1988) revealed undulations of 7- to 8-km wavelength in heat flow, indicating hydrothermal convection in the basement with a lateral extent of $3.5-4 \mathrm{~km}$ (Fig. 1).

The physical properties of sediments from this region of the eastern equatorial Pacific have been reported by a number of investigators. Wilkens and Langseth (1983) carried out a comprehensive program of physical-properties measurements on sediments recovered from Sites 504 and 505 and noted, in particular, a good correlation between water content and thermal resistivity. Karato and Becker (1983) described the physical properties of sediments from the Galapagos region and their implications for hydrothermal circulation. They examined sediments from 12 holes at five sites and noted the correlation between large gradients in physical properties and surface heat flow. The ODP Leg 111 Shipboard Scientific Party (1988) conducted a wide range of physical-properties measurements in a zone of low heat flow (Site 677) and in a zone of high heat flow (Site 678).

We report here some new data for the electrical properties of sediments in the region, together with an evaluation of the relationships of the physical properties to their stratigraphy and to the variations in heat flow. Further consideration is also given to the problems of core disturbance.

\section{STRATIGRAPHY OF HOLES 677A AND 678B}

The detailed stratigraphy of these two sites was described by the Shipboard Scientific Party (1988). The three major sedimen-

\footnotetext{
${ }^{1}$ Becker, K., Sakai, H., et al., 1989. Proc. ODP, Sci. Results, 111: College Station, TX (Ocean Drilling Program). U.K.

2 Department of Geology, University of Nottingham, Nottingham NG7 2RD,

${ }^{3}$ U.S. Geological Survey, Box 25046, M.S. 403, Denver Federal Center, Denver, CO 80225 .
}

tary units (plus a basal basalt unit) recognized at Site 677 are annotated alongside the corresponding physical-properties profiles in Figure 2. Lithologic Unit I consists of alternating clayey biogenic calcareous siliceous oozes and clayey biogenic siliceous calcareous oozes, lithologic Unit II consists of siliceous nannofossil ooze and chalk, and lithologic Unit III consists of cherty limestone and nannofossil chalk.

Three sedimentary units were also identified, again in addition to a basal unit, at Site 678 , though there is little vertical control on the overall lithostratigraphy because only a small part of the drilled section was cored (Fig. 3). Lithologic Unit I consists of clayey calcareous siliceous ooze, whereas lithologic Unit II consists of clayey diatom nannofossil chalk. Lithologic Unit III, which is not considered here, is composed of limestone fragments. Both basal units contain substantial basaltic material in a fragmented form.

\section{REGIONAL CORRELATION OF PHYSICAL PROPERTIES}

The sediments in the area around Site 504 are characterized by high porosity and water content. Figure 4 shows a comparison of the porosity vs. depth signatures for Holes $677 \mathrm{~A}, 678 \mathrm{~B}$, 504 , and 505 . Each profile starts near the surface with porosity values approaching $90 \%$. There is considerable scatter throughout, which may reflect real physical attributes or may be due to coring disturbance. Wilkens and Langseth (1983) noted similar gradients for Holes 504 and 505, with sediments above $145 \mathrm{~m}$ below seafloor (mbsf) exhibiting fairly uniform properties. Below this depth, the gradients increase, with another notable change at about 210 mbsf. There is surprisingly good correlation with both Holes 504 and 505 seen in the profile for Hole 677A. Although Hole 678B is shallower and the data are fewer in number, the porosity gradient appears generally steeper than for Hole $677 \mathrm{~A}$, even if the deepest values, which represent sediment at the boundary with the underlying igneous crust, are ignored. It is not possible to discuss any variations in gradient within Hole $678 \mathrm{~B}$ because of the sparsity of the data.

Examination of the physical-property profiles for Site 677 clearly reveals considerable variation with increasing depth in all measured parameters (Fig. 2). Many of the parameters are obviously interrelated (e.g., porosity, bulk density, and water content). In addition, many of the parameters individually show gross variations with depth that correspond with changes in both 


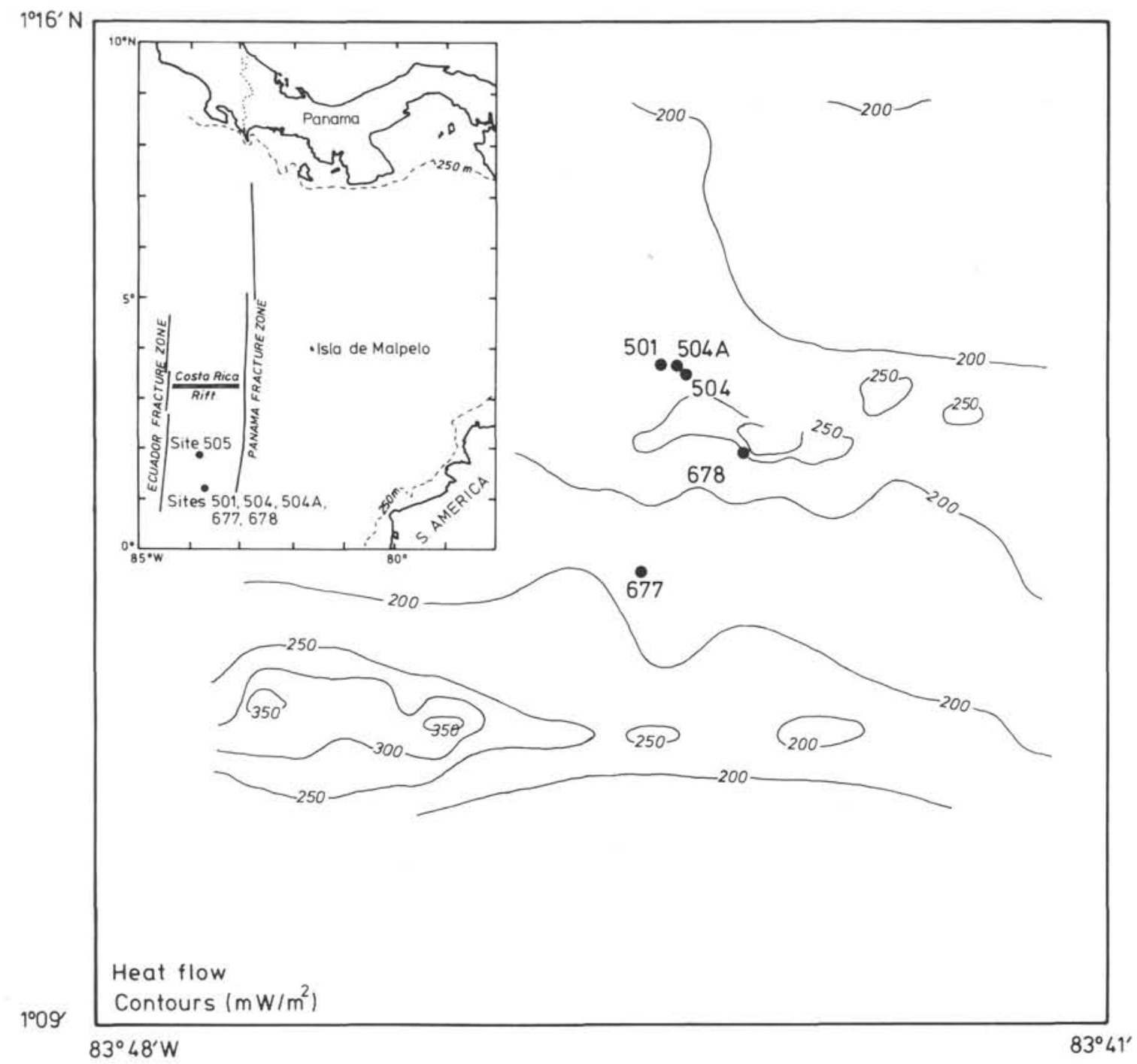

Figure 1. Location map showing Holes 501, 504, and 504A and Sites 677 and 678 . The inset map shows Site 505 to the north.

the lithologic units and, on a smaller scale, the lithologic subunits. An example of this correspondence is the zone of high water content which is limited to Subunit IA. The vane-shearstrength profile shows, quite dramatically, a different signature for Unit I in comparison with Unit II. Throughout Unit I vane shear strength increases gradually with depth. Similar effects are seen on each of the other profiles, indicating a dependence of physical properties such as shear strength on lithologic characteristics.

\section{Carbonate Content}

There is an excellent correlation between the carbonate content of the sediment and each of the subunits defined by the physical properties. Allowing for considerable "noise" or scatter of the values, which may or may not be representative of the in-situ conditions (see the following), it is possible to identify the boundaries of each subunit from a change in magnitude and/or gradient of the profile. This is also true of the profiles of the volumetric parameters and, to a lesser extent, thermal conductivity, velocity, and vane shear strength. Figure 5 is a crossplot of carbonate content vs. thermal conductivity for the three main sedimentary units. Each subunit is distinct, and, whilst there is obviously a continuum between each data set, there is also a clearly defined dependence of thermal conductivity on carbonate content. Less well-defined but similar relationships may be seen for Site 678 in Figures 3 and 6 .

\section{Thermal Conductivity}

Figure 7 is a plot of thermal conductivity vs. porosity for Sites 677 and 678 . A negative correlation is clearly discernable between the two parameters, with thermal conductivity increasing with decreasing porosity. The plot of thermal conductivity vs. carbonate content in Figure 5 shows a positive correlation between the two parameters, with thermal conductivity increasing with increasing carbonate content. Thus, as carbonate content increases the corresponding decrease in porosity effectively increases the thermal conductivity.

\section{Electrical Properties}

During Leg 111 the electrical resistivity of the sediments from Sites 677 and 678 was measured on the working half of the split cores using a four-electrode arrangement. These measurements were computed to give values of apparent formation factor $(F F)$ for the sediments, in which the formation factor is the 

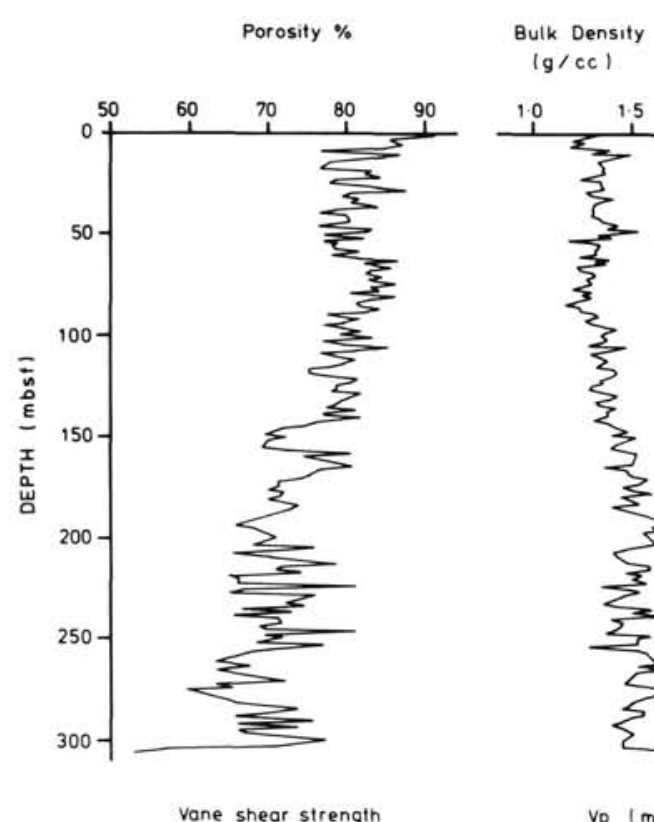

Water Content \%

Thermal Conductivity

( $\mathrm{W} / \mathrm{mK}$ )

Lithology
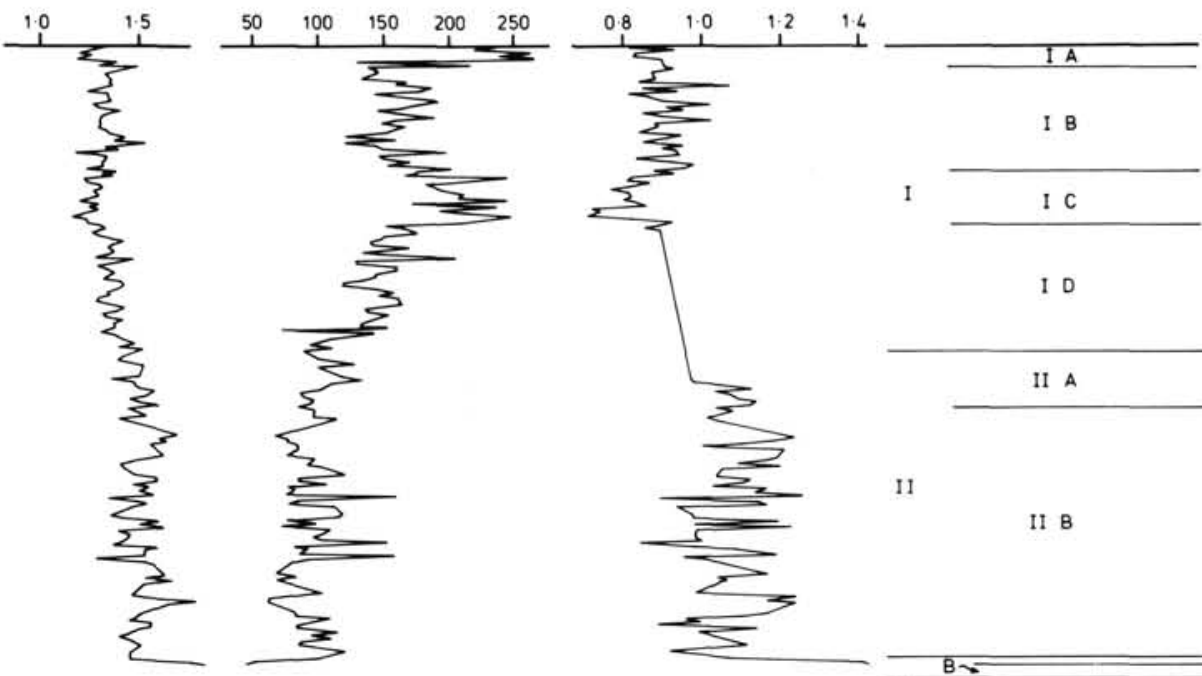

C

I D

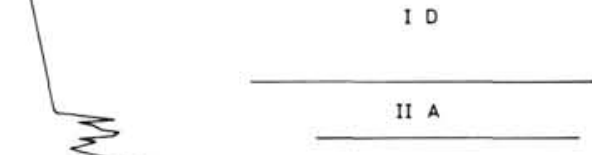

$(\mathrm{KPa})$

Vp $(\mathrm{m} / \mathrm{sec})$

Carbonate content $\%$

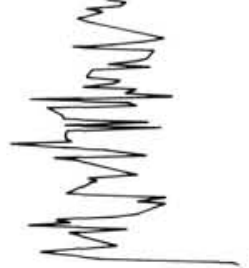

I1

II $B$
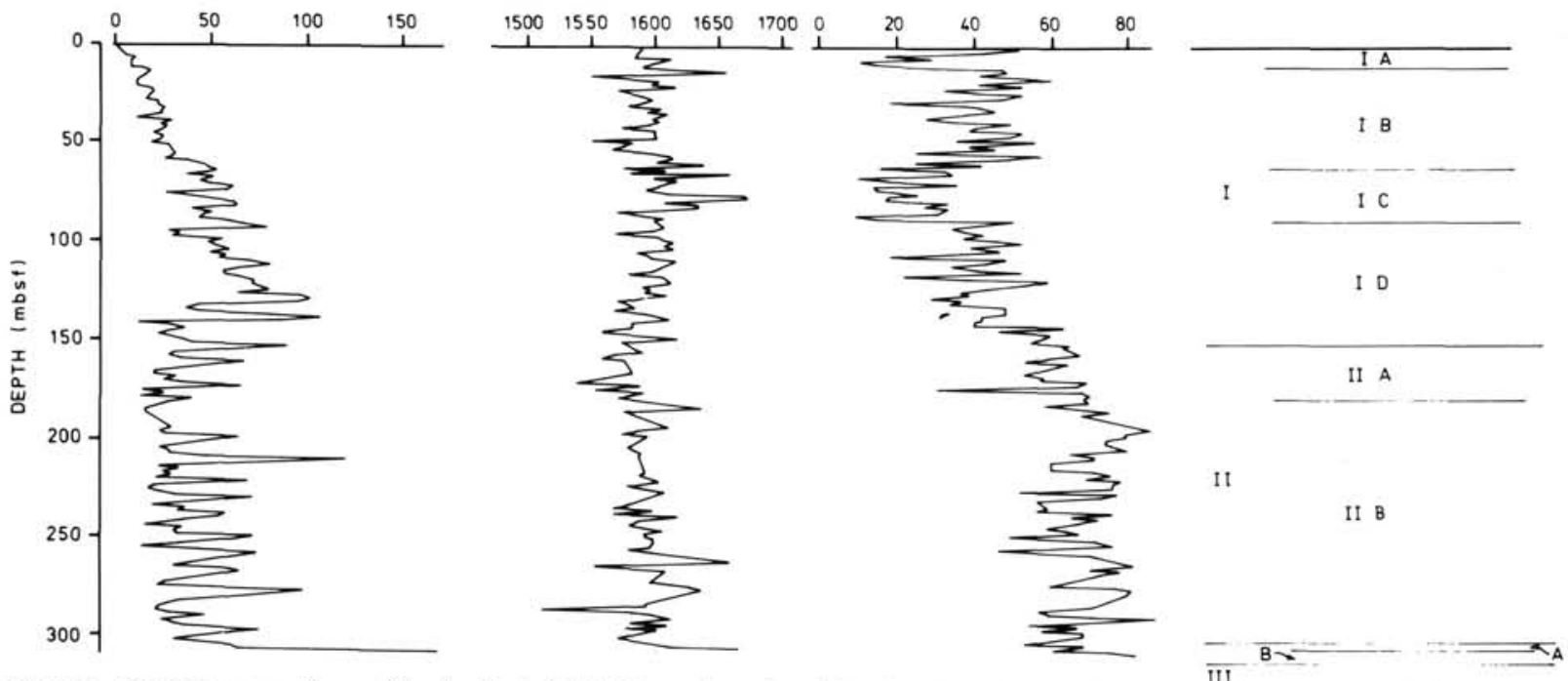

Figure 2. Physical-properties profiles for Hole 677A (thermal-conductivity data from both Holes 677A and 677B). Lithologic units from Shipboard Scientific Party (1988).

electrical resistivity of the core $\left(\rho_{s}\right)$, normalized with respect to the electrical resistivity of the pore fluid $\left(\rho_{f}\right)$ :

$$
F F=\rho_{s} / \rho_{f}
$$

The data plotted in Figure 8 show considerable scatter. Archie (1942) described an empirical relationship between electrical formation factor and porosity:

$$
F F=\phi^{-m},
$$

where $\phi$ is porosity and $m$ is an exponent commonly referred to as a cementation factor. Jackson et al.'s (1978) series of laboratory experiments on unconsolidated sands showed that $m$ increased from a minimum value of 1.4 for spherical particles to 2.0 for platelike particles. Lovell and Ogden (1984) reported similar results for deep-sea clays, but suggested that a law of the form presented by Winsauer et al. (1952) may be more appropriate. The reference lines in Figure 8 are for three different expo- nents in Archie's law, and certain data points that correlate with visible core disturbance are annotated. Also plotted are centerline features through two previously published data sets for deep-sea sediments. The apparent formation factor data for Hole 677A are plotted in Figure 9 against depth, together with similar measurements on cores recovered from other holes in the region. Only a gentle trend is discernible in both plots, which may be partly due to the high porosities of the sediments, whereas the scatter in the porosity plot may reflect the several different subunits represented.

\section{Core Disturbance at Sites 677 and 678}

An additional major factor in the scatter present in all of the physical-properties results is possibly core disturbance. Attention has already been drawn to the cyclical nature of the vaneshear-strength profile (Shipboard Scientific Party, 1988). Figure 10 shows power spectra for two sections of Hole 677A. The data are for measurements of compressional-wave velocity made us- 

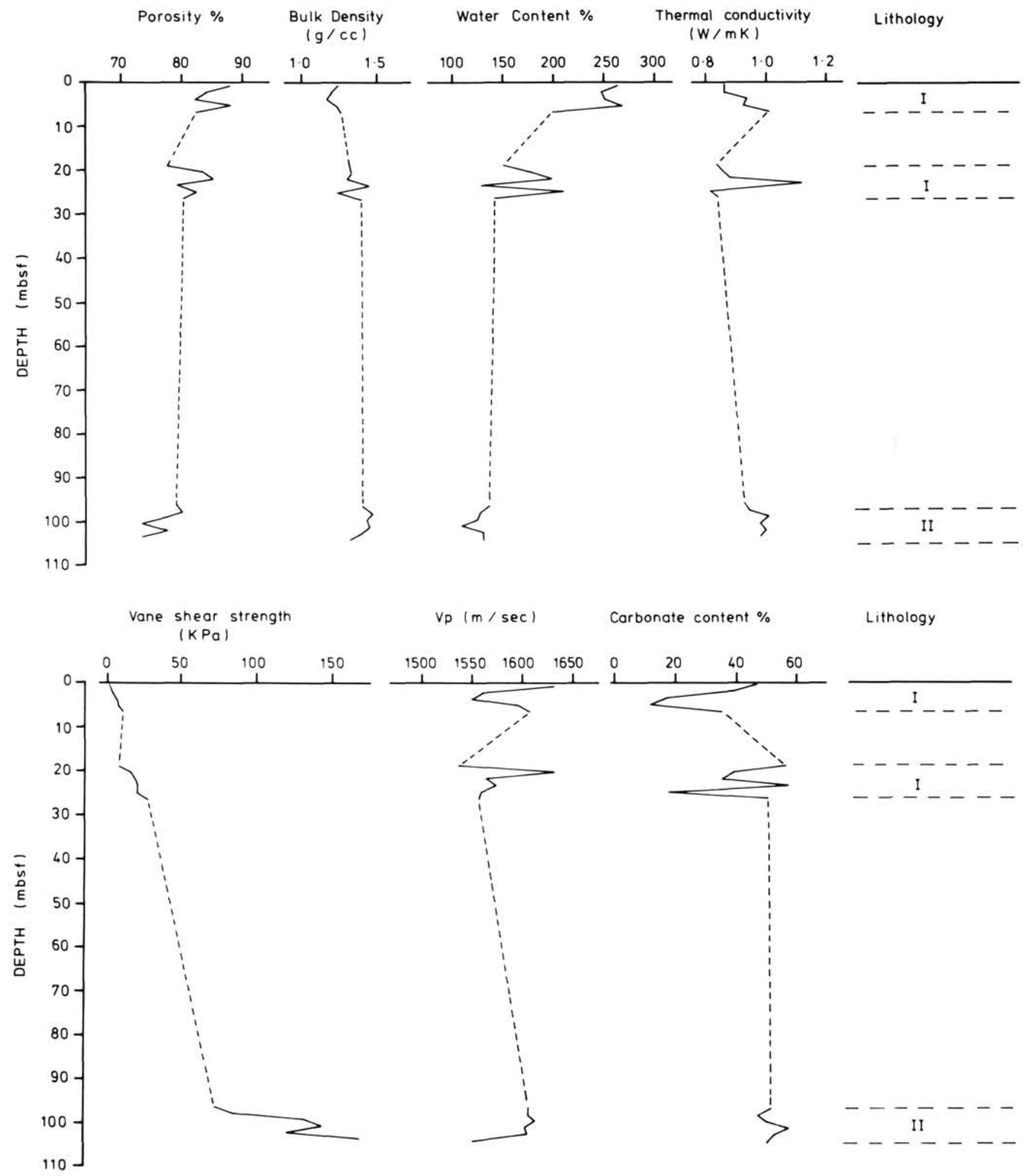

Figure 3. Physical-properties profiles for Hole 678B. Lithologic units from Shipboard Scientific Party (1988).

ing the $P$-wave logger. Although there are several peaks visible, it is worth noting that two peaks correlate closely with the typical length of the core-one peak ( $9.6 \mathrm{~m}$ at $154-212 \mathrm{mbsf})$ is especially disturbing. If this does represent the massive core disturbance it indicates, then we are probably degrading our data before we obtain them.

\section{WATER MOVEMENT THROUGH SEDIMENTS AND ITS EFFECTS UPON PHYSICAL PROPERTIES}

Cyclical variations in heat flow in this region (Langseth and Mottl, 1982) have been implied as evidence of the presence of 


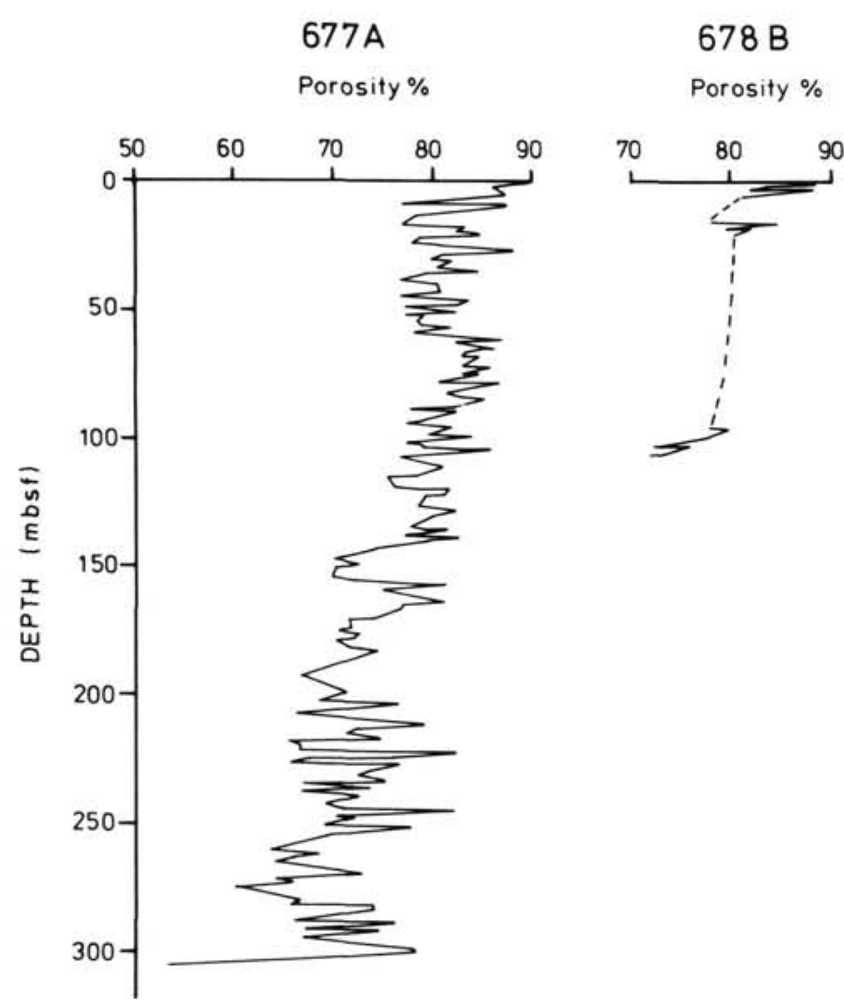

Figure 4. Porosity profiles for Holes 677A, 678B, 504, and 505.

active hydrothermal circulation in the shallow basement, which is manifested as a recurring pattern of heatflow highs and lows at the surface. Characteristic nonlinear temperature profiles that indicate water movement through the sedimentary column (Anderson et al., 1979; Langseth and Herman, 1981) have not been detected in this area and, consequently, heat transfer through the sediments has been assumed to be predominantly conductive.

In a recent study, however, Langseth et al. (1988) reported evidence from examination of pore-water chemistry profiles of very slow water movement through the sedimentary cap. These velocities are of the order of $6 \mathrm{~mm} / \mathrm{yr}$ and are too slow to be detected by thermal profiles. They are also too slow to significantly overconsolidate (downward flow) or underconsolidate (upward flow) the sediments by producing distinct changes in vertical effective stress. When exposed to velocities in the range of millimeters per year, these changes in maximum past effective stress will vary by only a few percent and are beyond the resolution capabilities of standard geotechnical laboratory tests (see Appendix). Therefore, water velocities of roughly $6 \mathrm{~mm} / \mathrm{yr}$ may not directly affect the mechanical characteristics of marine sediments.

This subtle water movement, however, may indirectly affect physical properties by influencing the local distribution of isotherms. There should be a vertical rise of isotherms associated with upward water percolation and a corresponding depression of isotherms coincident with downward movement of cooler ocean waters. This vertical shift in temperatures contours was recognized by Wilkens and Langseth (1983) as a primary cause for the early appearance of diagenesis in the sedimentary column at Hole 504.

\section{CONCLUSIONS}

Consideration of the physical properties of sediments recovered from several holes in the area around Hole 504B promotes the following conclusions:
Porosity \%

Porosity \%

$70 \quad 80$

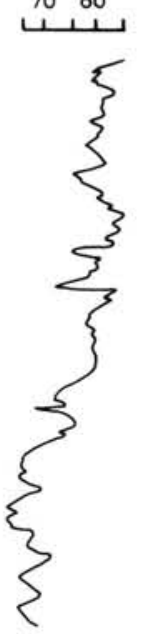

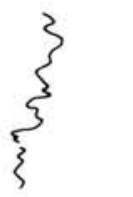

1. The sediments are generally characterized by high porosity and variable carbonate content.

2 . The overall lithostratigraphy of the sediment column correlates well with the physical-properties variations.

3 . The high porosities give rise to correspondingly low electrical formation factors.

4. The thermal conductivity of the sediments depends primarily on the porosity, although it also correlates with the carbonate content, which effectively controls the porosity.

5 . There is evidently a correlation between the compressionalwave velocity measured with the $P$-wave logger and the length of core. Power spectral analyses indicate that this may be due to disturbance of the sampled sediment resulting from the coring technique.

6. Analysis of the potential effects on the sediment of vertical fluid flow indicates that it is unlikely that the rates of flow present in the area would affect the mechanical characteristics.

\section{REFERENCES}

Anderson, R. N., Hobart, M. A., and Langseth, M. G., 1979. Geothermal convection through oceanic crust and sediments in the Indian Ocean. Science, 204:828-832.

Anderson, R. N., and Zoback, M. D., 1982. Permeability, underpressures, and convection in the oceanic crust near the Costa Rica Rift, eastern equatorial Pacific. J. Geophys. Res., 87:2860-2868.

Archie, G. E., 1942. The electrical resistivity $\log$ as an aid in determining some reservoir characteristics. Trans. Am. Inst. Min., Metall. Pet. Eng., 146:54-62.

Boyce, R. E., 1980. Determination of the relationships of electrical resistivity, sound velocity and density/porosity of sediment and rock by laboratory techniques and well logs from DSDP Sites 415 and 416 off the coast of Morocco. In Lancelot, Y., Winterer, E. L., et al., Init. Repts. DSDP, 50: Washington (U.S. Govt. Printing Office), 305-318.

Bryant, W. R., Hottman, W., and Trabant, P., 1975. Permeability of unconsolidated and consolidated marine sediments, Gulf of Mexico. Mar. Geotechnol., 1:1-13. 
Jackson, P. D., Taylor Smith, D., and Stanford, P. N., 1978. Resistivityporosity-particle shape relationships for marine sands. Geophysics, 43:1250-1268.

Karato, S., and Becker, K., 1983. Physical properties of sediments from the Galapagos region and their implications for hydrothermal circulation. In Honnorez, J., Von Herzen, R. P., et al., Init. Repts. DSDP, 70: Washington (U.S. Govt. Printing Office), 355-368.

Lambe, T. W., and Whitman, R. V., 1969. Soil Mechanics: New York (Wiley).

Langseth, M. G., and Herman, B. M., 1981. Heat transfer in the oceanic crust of the Brazil Basin. J. Geophys. Res., 86:10,805-10,819.

Langseth, M. G., and Mottl, M. J., 1982. Geochemical and geothermal mapping of crustal circulation patterns near DSDP Site 501/504. EOS, Trans. Am. Geophys. Union, 63:1116.

Langseth, M. G., Mottl, M. J., Hobart, M. A., and Fisher, A., 1988. The distribution of geothermal and geochemical gradients near Site 501/504: implications for hydrothermal circulation in the oceanic crust. In Becker, K., Sakai, H., et al., Proc. ODP, Init. Repts., 111: College Station, TX (Ocean Drilling Program), 23-32.

Lovell, M. A., and Ogden, H. L., 1984. Remote Assessment of Permeability/Thermal Diffusivity of Consolidated Clay Sediments: Comm. Eur. Communities, Rep. EUR, 9206.
Morin, R. H., and Von Herzen, R. P., 1985. Geothermal measurements at Deep Sea Drilling Project Site 587. In Kennett, J. P., von der Borch, C. C., et al., Init. Repts. DSDP, 90: Washington (U.S. Govt. Printing Office), 1317-1324.

Silva, A. J., Hetherman, J. R., and Calnan, D. I., 1979. Low gradient permeability testing of fine-grained marine sediments. In Zimmie, T. F., and Riggs, C. O. (Eds.), ASTM Symposium on Permeability and Groundwater Contaminant Transport: ASTM Spec. Tech. Publ., 113-125.

Shipboard Scientific Party, 1988. Sites 677 and 678. In Becker, K., Sakai, H., et al., Proc. ODP, Init. Repts., 111: College Station, TX (Ocean Drilling Program), 253-348.

Wilkens, R. H., and Langseth, M. G., 1983. Physical properties of sediments of the Costa Rica Rift, Deep Sea Drilling Project Sites 504 and 505. In Cann, J. R., Langseth, M. G., et al., Init. Repts. DSDP, 69: Washington (U.S. Govt. Printing Office), 659-674.

Winsauer, W. O., Shearin, A. M., Masson, P. H., and Williams, M., 1952. Resistivities of brine saturated sands in relation to pore geometry. AAPG Bull., 36:253.

Date of initial receipt: 11 July 1988

Date of acceptance: 8 May 1989

Ms 111B-144

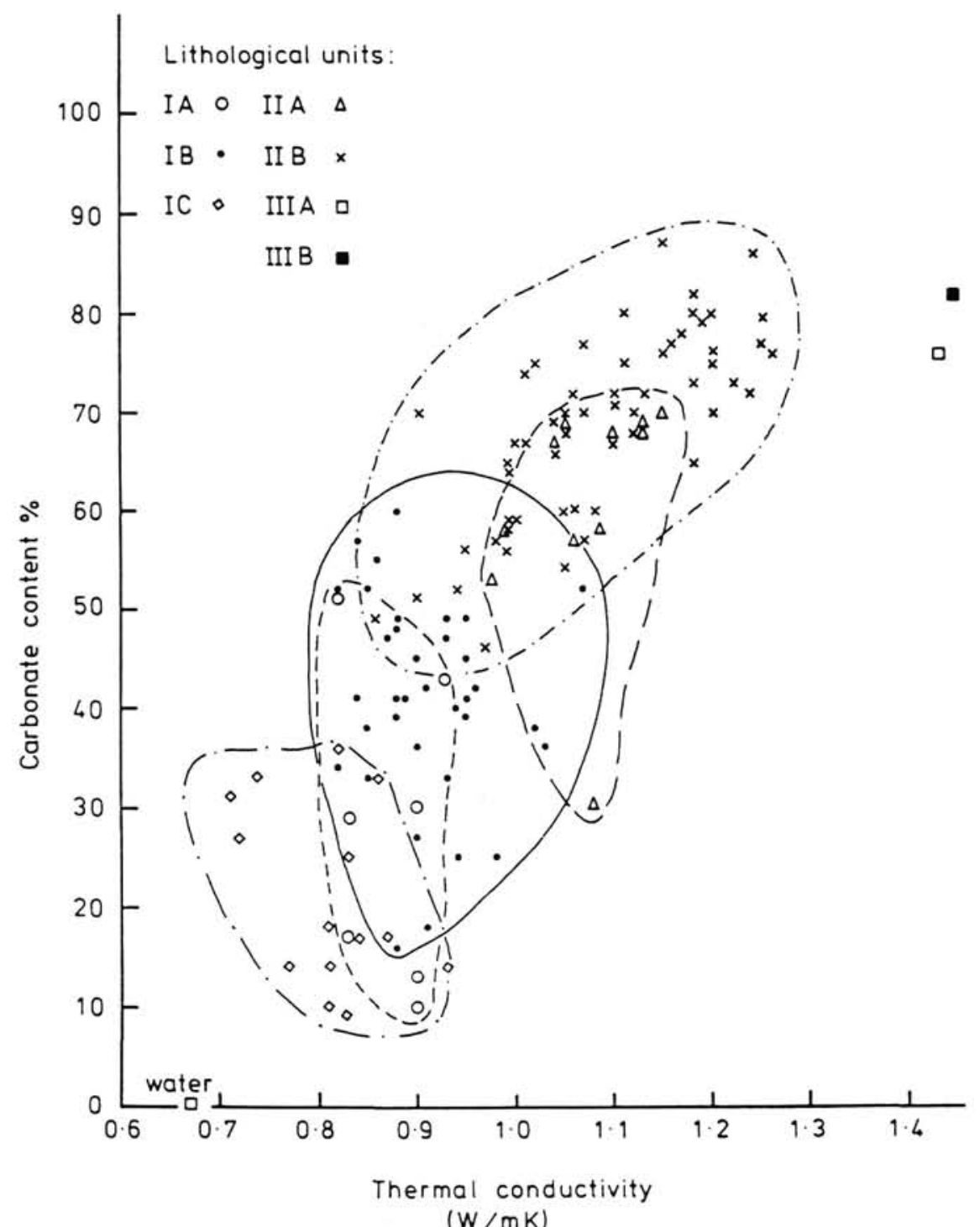

Figure 5 . Thermal conductivity vs. carbonate content for Holes $677 \mathrm{~A}$ and $677 \mathrm{~B}$, coded by lithologic unit. 


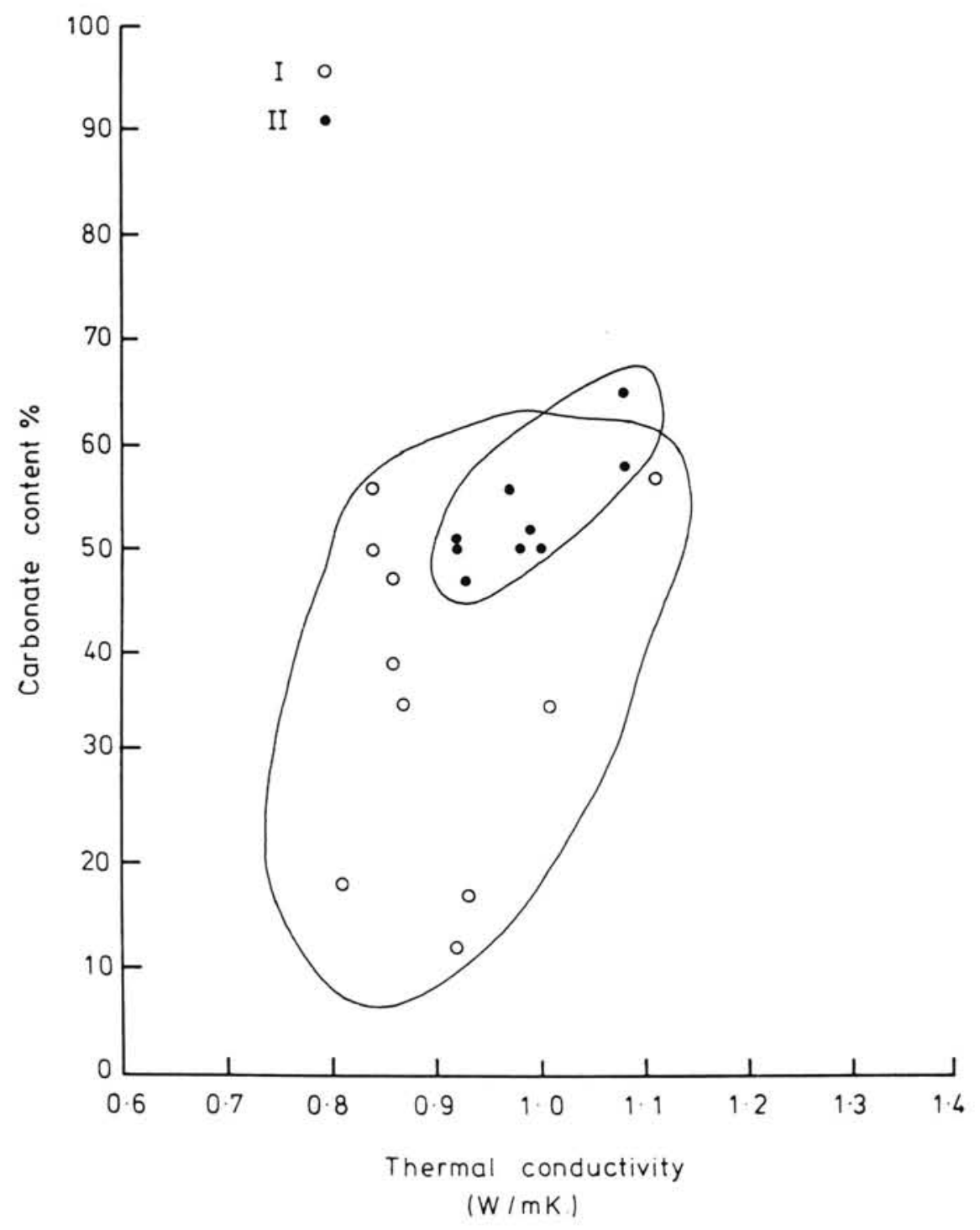

Figure 6 . Thermal conductivity vs. carbonate content for Hole $678 \mathrm{~B}$, coded by lithologic unit. 


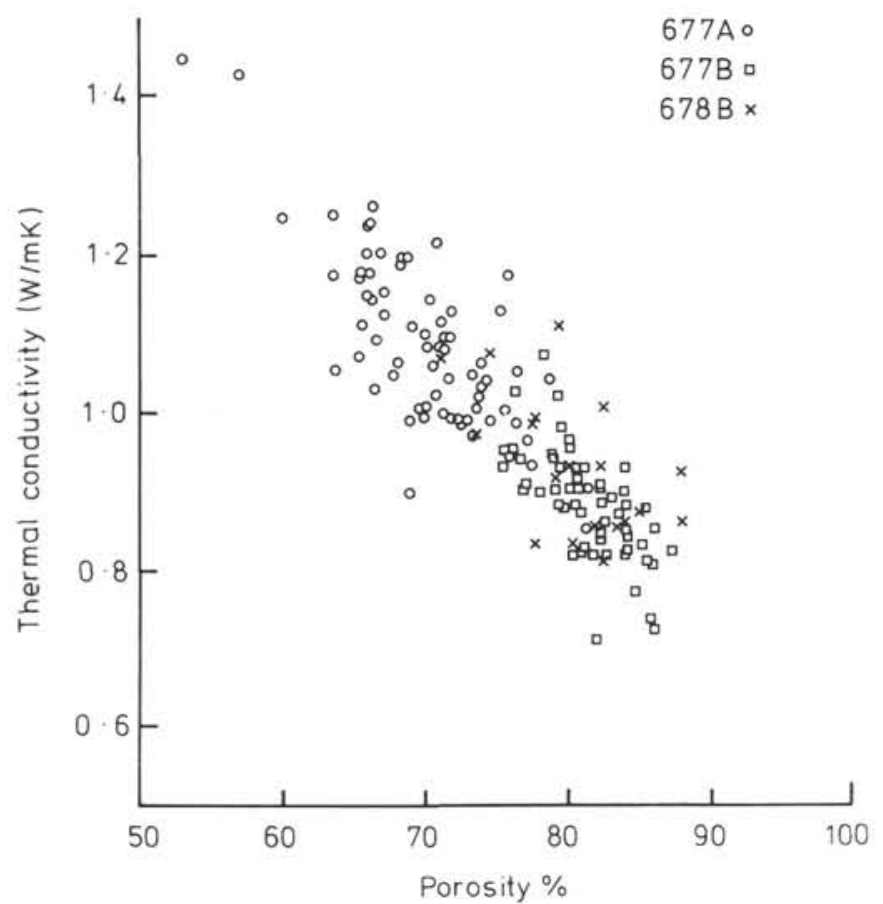

Figure 7. Thermal conductivity vs. porosity for Holes 677A, 677B, and 678B. 


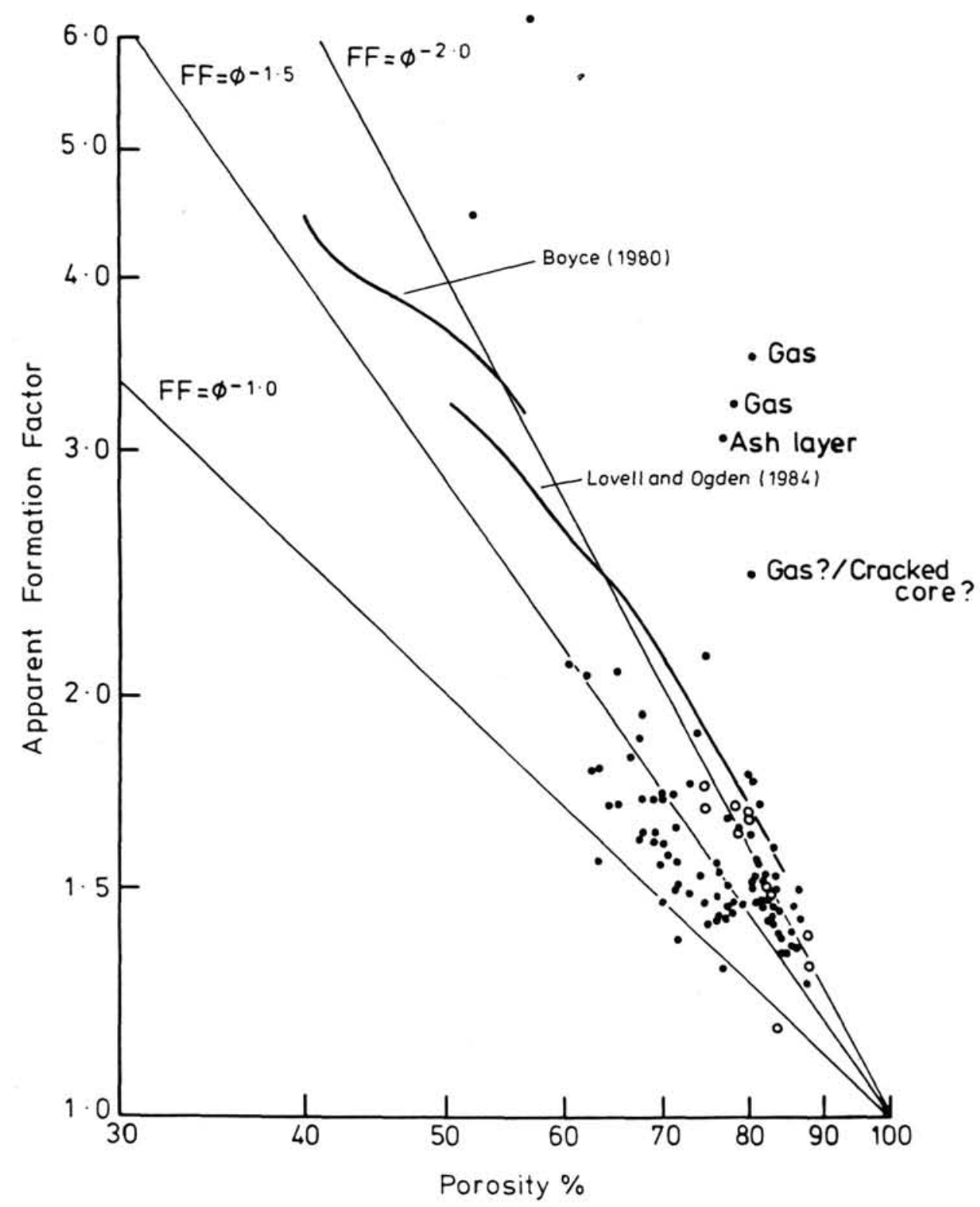

Figure 8. Apparent electrical formation factor vs. porosity for samples from Sites 677 (solid circles) and 678 (open circles). 


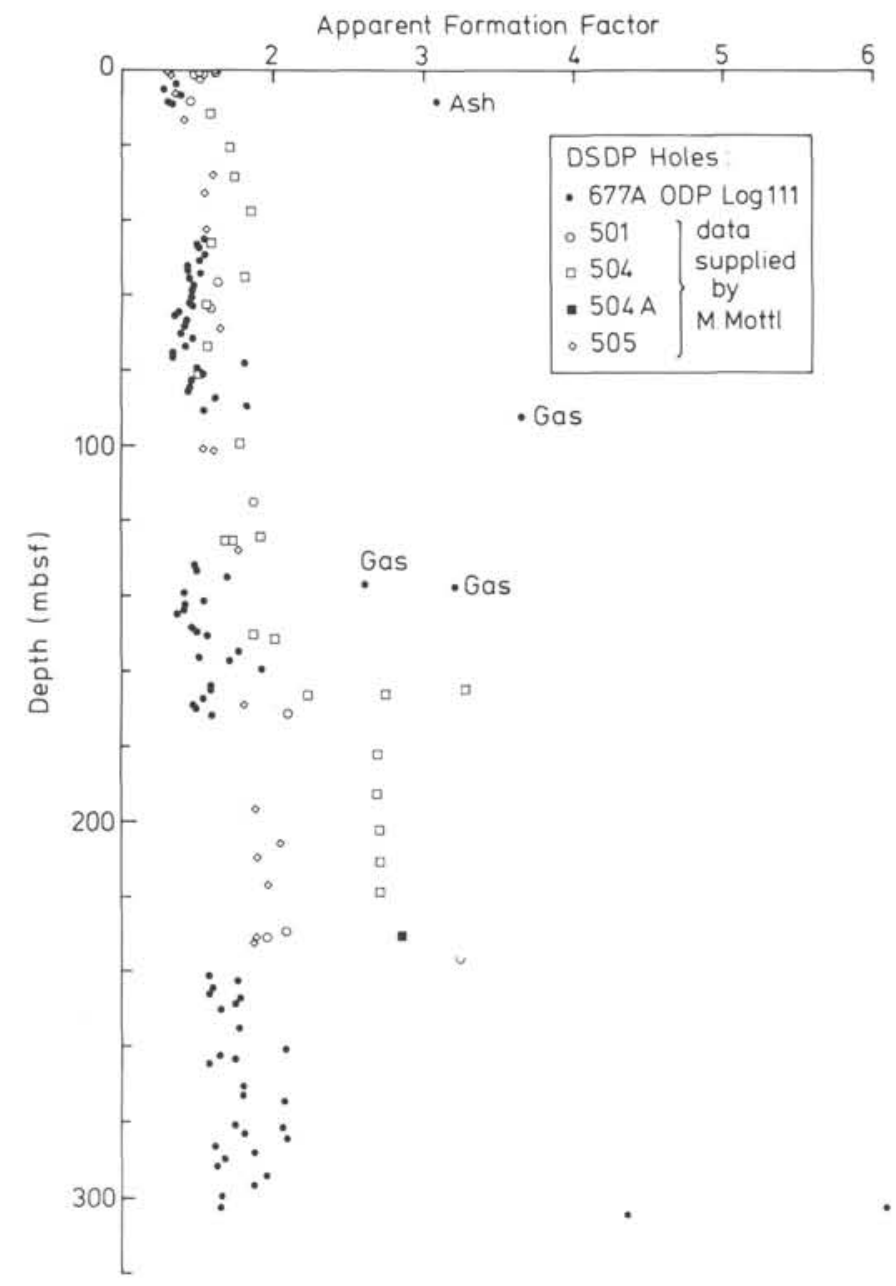

Figure 9. Apparent electrical formation factor profile for five holes in the eastern equatorial Pacific. 

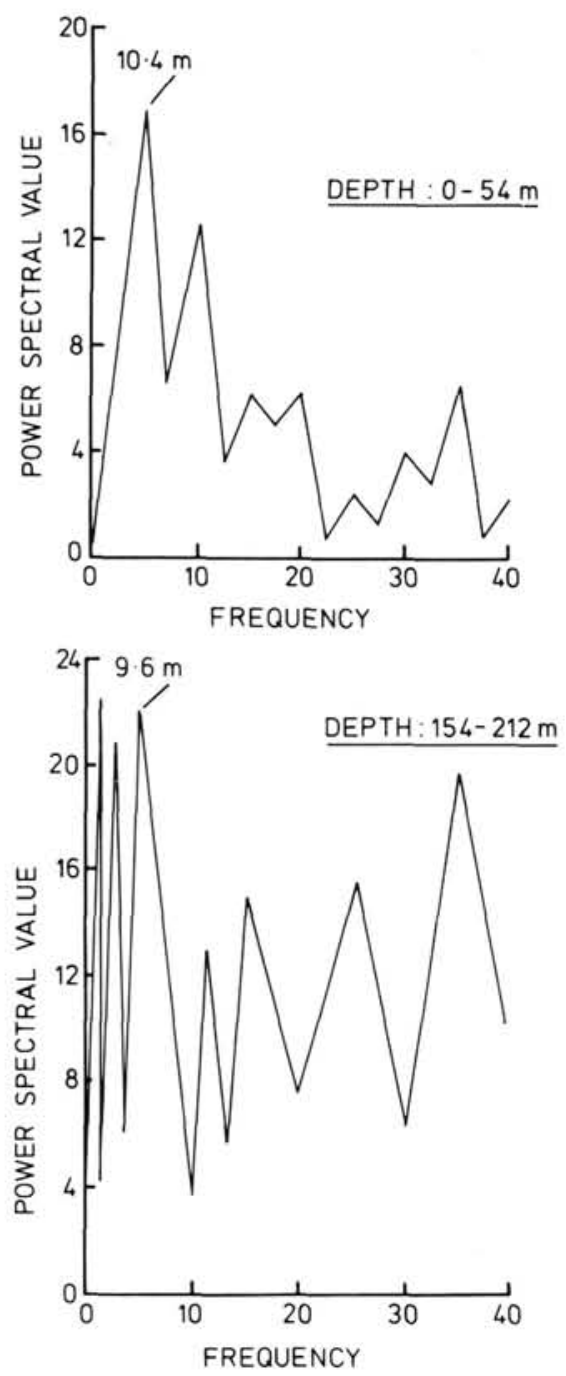

Figure 10. Power spectra of $P$-wave-logger data for two sub-bottom depth intervals at Site 677.

\section{APPENDIX}

Overconsolidation of Sediments as a Result of Vertical Fluid Flow

Although the permeability of sediment samples recovered from Hole 504 was not measured, it is possible to estimate this property from laboratory results reported in the literature. Silva et al. (1979) presented data showing that calcareous oozes with an average porosity of about $75 \%$ have hydraulic conductivities on the order of $10^{-5} \mathrm{~cm} / \mathrm{s}$. Bryant et al. (1975) reported that silty clays with this same porosity have hydraulic conductivities closer to $10^{-7} \mathrm{~cm} / \mathrm{s}$. For the purposes of this exercise, the average sediment hydraulic conductivity $(K)$ at Hole 504B is assumed to be $10^{-6} \mathrm{~cm} / \mathrm{s}$, and other values are as follows:

Average porosity $(\phi)=0.75$ (Fig. 4)

Specific gravity of solids $(G)=2.75 \mathrm{~g} / \mathrm{cm}^{3}$

Unit weight of seawater $\left(\gamma_{w}\right)=1.03 \mathrm{~g} / \mathrm{cm}^{3}$

Vertical fluid velocity $(V)=6 \mathrm{~mm} / \mathrm{yr}\left(\sim 2 \times 10^{-8} \mathrm{~cm} / \mathrm{s}\right)$.

From Darcy's law:

$$
V=K i,
$$

where $i=0.02$, the value of the hydraulic gradient required to force water through the sedimentary column at a velocity of $6 \mathrm{~mm} / \mathrm{yr}$. Referring to Appendix Figure 1, when there is no flow, the effective stress at point A can be computed as follows:

$$
\begin{aligned}
\sigma_{\text {no flow }}^{\prime} & =\sigma-\mu \\
& =\left(\gamma_{w}+\gamma_{b}\right) h_{1}-\gamma_{w} h_{1} \\
& =\gamma_{b} h_{1},
\end{aligned}
$$

where $\sigma^{\prime}$ is effective stress, $\sigma$ is total stress, $\mu$ is pore pressure, and $\gamma_{b}$ is the buoyant weight of the sediment. Once upward flow has been induced by the introduction of a hydraulic head $\left(h_{2}\right)$, as shown in Appendix Figure 2, a new effective stress at point $\mathrm{A}$ is produced:

$$
\begin{aligned}
\sigma^{\prime} \text { flow } & =\sigma-\mu \\
& =\left(\gamma_{w}+\gamma_{b}\right) h_{1}-\gamma_{\mathrm{w}}\left(h_{1}+h_{2}\right) \\
& =\gamma_{b} h_{1}-\gamma_{b} h_{2}
\end{aligned}
$$

The overconsolidation ratio $(O C R)$ is defined as (Lambe and Whitman, 1969)

$$
\begin{aligned}
O C R & =\sigma^{\prime} \text { flow } / \sigma^{\prime} \text { no flow } \\
& =\left(\gamma_{b} h_{l}-\gamma_{w} h_{2}\right) / \gamma_{b} h_{1},
\end{aligned}
$$

but hydraulic gradient $i=h_{2} / h_{1}=0.02$, and $h_{2}=0.02 h_{1}$. Thus,

$$
O C R=\left(\gamma_{b}-0.02 \gamma_{w}\right) / \gamma_{b},
$$

but,

$$
\begin{gathered}
\gamma_{b}=\gamma_{w}(\mathrm{G}-1)(1-\phi)=0.45 \\
O C R=0.95 .
\end{gathered}
$$

Similarly, for downward flow, $O C R \sim 1.05$. These results demonstrate that for velocities in the range of millimeters per year, associated changes in $O C R$ are negligible and cannot be detected given the resolution limitations of routine geotechnical tests.

It should be noted that Langseth et al. (1988) postulated that sediment permeabilities in this region may be closer to $10^{-7} \mathrm{~cm} / \mathrm{s}$, based on underpressures of approximately 8 bars in the permeable upper basement reported by Anderson and Zoback (1982). If the preceding analysis is repeated with this lower value of $K$, estimates of $O C R$ become significant and large enough to be determined experimentally. For downward flow, the $O C R$ becomes 1.84; for upward flow, $O C R$ equals 0.54 . This latter value approaches the threshold gradient required to produce a "quick" condition (Morin and Von Herzen, 1985), where the overpressure beneath the sedimentary cap exceeds the lithostatic load and

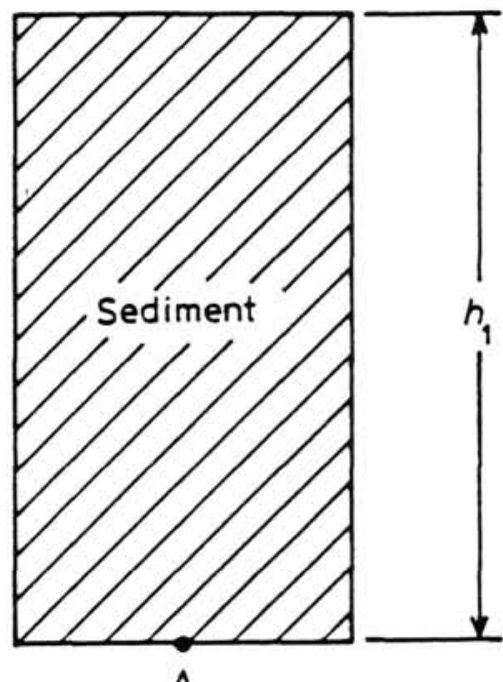

A

Appendix Figure 1. Sediment sample at no flow conditions. 


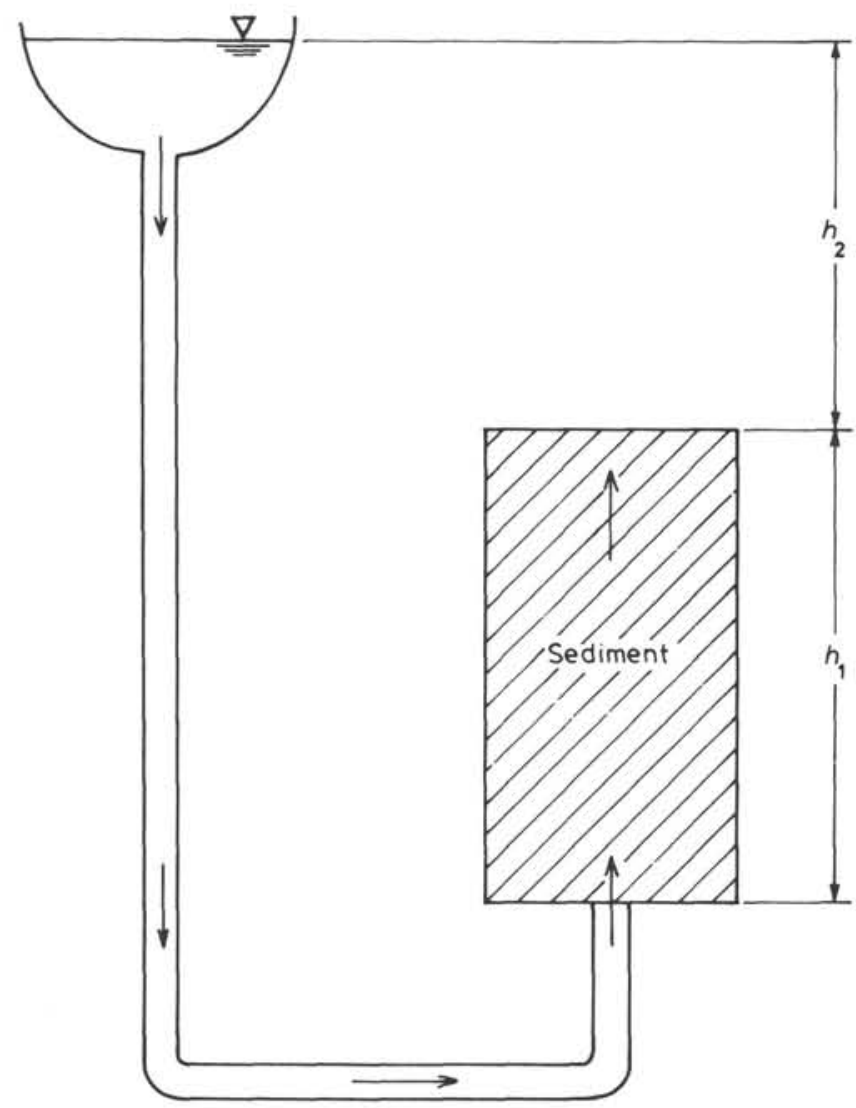

Appendix Figure 2. Sediment sample during upward flow. sediment grains become suspended in fluid, unable to support vertical loading. This situation does not seem likely and is not supported by inspection of the sediment cores.

Regrettably, no permeability measurements were conducted on any sediment samples recovered from Hole 504B, and only general assumptions can be made regarding the magnitude of this transport property. If sediment permeability is on the order of $10^{-6} \mathrm{~cm} / \mathrm{s}$ or greater, then water velocities of about $6 \mathrm{~mm} / \mathrm{yr}$ should have no significant effect on the mechanical characteristics of the sediments. If permeabilities are an order of magnitude lower, however, then laboratory consolidation studies should be able to detect the consequences of water movement. These lower permeabilities seem unlikely, however, because the degree of underconsolidation resulting from upward percolation would approach an unstable, "quick" condition. 